\title{
The Visibility of Oral Corrective Feedback Research in Teacher Education Textbooks
}

\section{Majid Nikouee E Leila Ranta}

The issue of whether, when, and how to respond to learners' oral errors is something every teacher has to consider. Early studies of teachers' feedback practices consisted of observations of how they managed this complex process (e.g., Lyster $\mathcal{E}$ Ranta, 1997). Beginning with these descriptions, a large body of research on types of oral corrective feedback (OCF) and their relative impact on L2 learning has emerged over the past few decades. OCF is thus an ideal topic for examining the degree to which second language acquisition (SLA) research-based discourse has influenced pedagogical discourse (Ellis $\mathcal{E}$ Shintani, 2014). This study examined how the topic of OCF is represented in 30 textbooks used in language teacher education courses. The amount of text dealing with OCF and the number of cited SLA references were quantified, and the textbooks' advice was analyzed and compared to the findings from research. The results revealed variability across the textbooks in the degree to which OCF is treated, what is said about $i t$, and the extent to which research is cited. Some textbook authors clearly have chosen not to highlight the contribution of research for language teaching, thus potentially limiting novice teachers' exposure to researchers' insights about error correction.

La question de savoir s'il faut réagir aux erreurs orales des apprenants, quand et comment y réagir doit se poser à chaque enseignant. Les premières études sur les pratiques de rétroaction des enseignants étaient composées d'observations sur la façon dont ils géraient ce processus complexe (par ex., Lyster \& Ranta, 1997). À partir de ces descriptions, un vaste corpus de recherche sur les types de rétroaction corrective orale (RCO) et sur leur impact relatif sur l'apprentissage de la langue seconde a vu le jour au cours des quelques dernières décennies. Par conséquent, la RCO est un sujet idéal pour examiner dans quelle mesure le discours fondé sur la recherche en matière d'acquisition de la langue seconde (ALS) a influencé le discours pédagogique (Ellis $\mathcal{E}$ Shintani, 2014). Cette étude examine comment le sujet de la RCO est représenté dans 30 manuels utilisés dans les cours de formation des enseignants de langue. On a quantifié le nombre de textes parlant de la RCO ainsi que le nombre de références d'ALS citées, et les conseils fournis par les manuels ont été analysés et comparés aux résultats de la recherche. Les résultats de ce travail ont révélé une variabilité entre les manuels par rapport à la mesure dont on traitait de la $R C O$, ce qu'on en disait, ainsi que le degré où l'on citait la recherche. Certains auteurs de manuels ont clairement choisi de ne pas souligner la contribution de la recherche sur l'enseignement des langues, limitant de ce fait l'exposition des enseignants novices aux perspectives des chercheurs sur la correction des erreurs.

Keywords: oral corrective feedback, pedagogical discourse, researcher discourse, textbook analysis 
Publicly funded agencies like the Social Sciences and Humanities Research Council of Canada actively promote what has come to be called "knowledge dissemination" or "knowledge transfer" from the researcher to the public. Educational research aims to extend our understanding of how people learn in classroom settings and how instruction can help learners learn. Despite a shared interest in classroom teaching, the relationship between researchers and practitioners is consistently depicted metaphorically as that of a divide or a gap. According to Labaree (2003), the two groups have contrasting worldviews: the researcher's can be characterized as being analytical, intellectual, universal, and theoretical, whereas the practitioner's is normative, personal, particular, and experiential. In the context of second language acquisition (SLA), the question is whether the findings from research have any impact on second language (L2) teaching. Our aim in this study was to examine whether there is a divide between these two domains with respect to the topic of oral corrective feedback (OCF). Since all language teachers have to decide whether, when, and how to respond to their learners' oral errors, the topic of OCF is very relevant to practitioners. In addition, a large body of empirical evidence relating to feedback has emerged over the past few decades. This makes OCF an ideal topic for examining knowledge transfer.

\section{Literature Review}

This section contains a brief review of some of the trends in the OCF research literature and then discusses the distinction between research-based and pedagogical discourse (Ellis \& Shintani, 2014).

\section{Summary of Findings from OCF Research}

The literature on oral corrective feedback is massive and variegated. Recent reviews cite hundreds of empirical studies, using different research methods and conducted in a wide range of L2 learning settings. A comprehensive review of the literature on $\mathrm{CF}$ is thus well beyond the scope of this paper. The interested reader is directed to syntheses presented in review articles (e.g., Loewen, 2012; Lyster et al., 2013; Sheen \& Ellis, 2011), meta-analyses (Li, 2010; Lyster \& Saito, 2010; Mackey \& Goo, 2007; Russell \& Spada, 2006), and handbooks (e.g., Nassaji \& Kartchava, 2017). This extensive body of research on CF is fairly recent. Prior to 1997, there were few empirical studies of feedback practices in classroom settings (e.g., Chaudron, 1977; Fanselow, 1977). It was the study of teacher feedback on learners' errors in French immersion classes by Lyster and Ranta (1997) that opened the floodgates for scholarly engagement with the topic of OCF. In their paper, Lyster and Ranta proposed a number of conceptual tools that have become a mainstay of CF research: a typology of CF techniques, the notion of learner uptake, and the significance of self-repairs. They applied these concepts to 
classroom interaction data from primary-level French immersion classrooms; other researchers have used the categories and concepts for understanding interaction in other instructional settings (e.g., Sheen, 2004). They observed that French immersion teachers' responses to their learners' oral errors could be described in terms of six types of corrective feedback: recast, elicitation, metalinguistic feedback, clarification request, explicit correction, and repetition. These CF strategies can be grouped into two broad categories: (1) input-providing strategies that supply the correct form via either recasts or explicit correction and (2) output-prompting strategies that elicit the correct form from learners via elicitations, clarification requests, metalinguistic feedback, or repetition.

In addition to the typology of OCF moves, Lyster and Ranta (1997) posited that learners' response to their teachers' corrective feedback moves (i.e., "the third turn") provides evidence of whether the feedback was noticed and understood (i.e., uptake). The concept of uptake has fueled much research since then. In Lyster and Ranta (1997), recasts typically did not lead to student repair of their errors. In contrast, elicitation almost always led to self-repair. Lyster and Ranta argued that, given low rates of self-repair following recasts, there is no evidence that they are noticed by learners whereas when self-repair occurs, the feedback can be assumed to have been noticed. Furthermore, the act of producing a self-repair (modified output) offers cognitive benefits such as the generation effect, hypothesis-testing, and practice.

One reason why Lyster and Ranta (1997) triggered an explosion of OCF research is that, at the time, many scholars believed in the superiority of recast, due to the fact that it draws learners' attention to form implicitly, without disrupting the flow of communication, at the moment when the learner is focused on meaning (e.g., Long \& Robinson, 1998). However, studies that compared the impact of input-providing recasts to output-prompting OCF have shown an advantage for the latter (e.g., Ellis et al., 2006; Lyster \& Saito, 2010).

Although the final chapter has not been written on this topic and different aspects of OCF are still open to debate, it is possible to state a number of generalizations about OCF drawn from the compilations of findings from various reviews. Specific issues that have been explored by researchers include frequency and distribution of different types of CF in classroom settings, learner noticing of $\mathrm{CF}$, the effectiveness of different types of feedback on language development, and learner and teacher preferences for different types of CF. The generalizations shown in Table 1 are derived from a number of studies published in academic journals or books; they suggest a possible tension between a preference for recasts on the part of practitioners with respect to their feedback practices (e.g., Sheen, 2004) and expressed preferences (e.g., Bell, 2005) and the empirical evidence demonstrating the superiority of other types of OCF. 
Table 1

Findings from Select CF Research

\begin{tabular}{|c|c|c|}
\hline Type of research & Generalization & Sample study \\
\hline $\begin{array}{l}\text { Classroom } \\
\text { observation }\end{array}$ & $\begin{array}{l}\text { Teachers use recasts more than other types } \\
\text { of CF. }\end{array}$ & $\begin{array}{l}\text { Ellis et al. (2001); } \\
\text { Jensen (2001); Lyster } \\
\text { \& Ranta (1997); } \\
\text { Sheen (2004) }\end{array}$ \\
\hline Teacher cognition & Teachers express preference for recasts. & $\begin{array}{l}\text { Bell (2005); Schulz } \\
\text { (2001); Brown (2009) }\end{array}$ \\
\hline $\begin{array}{l}\text { Learners' } \\
\text { preference }\end{array}$ & $\begin{array}{l}\text { Learners express preference for immediate } \\
\text { correction and output-prompting feedback }\end{array}$ & $\begin{array}{l}\text { Brown (2009); } \\
\text { Kaivanpanah et al. } \\
\text { (2015); Lee (2013); } \\
\text { Yoshida (2008); Zhu } \\
\text { \& Wang (2019) }\end{array}$ \\
\hline \multirow[t]{4}{*}{$\begin{array}{l}\text { Experimental } \\
\text { studies }\end{array}$} & $\begin{array}{l}\text { Prompts are more noticeable than recasts } \\
\text { unless the saliency of the latter is enhanced } \\
\text { by, for example, rising intonation. }\end{array}$ & $\begin{array}{l}\text { Ammar (2008); } \\
\text { Kartchava \& Ammar } \\
\text { (2014); Takahashi } \\
\text { (2014) }\end{array}$ \\
\hline & $\begin{array}{l}\text { Impact on L2 learning: Output-prompting } \\
\text { feedback superior to input-providing } \\
\text { feedback. }\end{array}$ & $\begin{array}{l}\text { Lyster (2004); Ellis } \\
\text { et al. (2006); Van de } \\
\text { Guchte et al. (2015) }\end{array}$ \\
\hline & $\begin{array}{l}\text { Peer-feedback can lead to gains in accuracy } \\
\text { and fluency, and learners benefit from it if } \\
\text { they are cognizant of the value of } L 2 \text { learning } \\
\text { in a collaborative context free of stigmatizing } \\
\text { pressure. }\end{array}$ & $\begin{array}{l}\text { Fuji et al. (2016); } \\
\text { Sato \& Lyster (2012) }\end{array}$ \\
\hline & $\begin{array}{l}\text { In terms of OCF timing, immediate feedback } \\
\text { could be as effective as and under certain } \\
\text { conditions more effective than delayed } \\
\text { feedback. }\end{array}$ & $\begin{array}{l}\text { Arroyo \& Yilmaz } \\
\text { (2018); Li (2020); } \\
\text { Quinn (2014) }\end{array}$ \\
\hline Meta-analyses & $\begin{array}{l}\text { Mean effect sizes are medium sized or large } \\
\text { in favour of output-prompting over input- } \\
\text { providing OCF moves }\end{array}$ & $\begin{array}{l}\text { Lyster \& Saito (2010); } \\
\text { Russell \& Spada } \\
\text { (2006) }\end{array}$ \\
\hline
\end{tabular}

\section{Pedagogical Recommendations about Correcting Learners' Errors}

From Table 1, we can conclude that researchers do have some insights to share with teachers about providing feedback on learners spoken errors. Indeed, some researchers have attempted to bridge the divide between research and practice by formulating guidelines for teaching. For example, Ellis (2009, p. 14) offers a list of 10 guidelines for correcting errors based on the SLA literature. The principles that can be readily connected to empirical studies (as in Table 1) are: 
"CF (both oral and written) works and so teachers should not be afraid to correct students' errors. This is true for both accuracy and fluency work, so CF has a place in both." (\#2)

"Teachers should ensure that learners know they are being corrected." (\#4)

"Teachers need to create space following the corrective move for learners to uptake the correction." (\#7)

In these selected principles, Ellis emphasizes that feedback is effective and highlights the need for noticing and for providing learners with the opportunity to repair their errors, concepts from the OCF literature. Teachers are likely to comprehend Ellis' recommendations since they are expressed in a straightforward manner, without heavy use of SLA technical jargon. Nevertheless, useful as these guidelines might be, they are unlikely to be read by practicing language teachers (unless they are completing a graduate degree) because they are found in scholarly journal articles. Teachers are typically reluctant to interact with SLA research, which is often presented in academic journals, since it makes use of a technical language that may be unfamiliar to them, and its findings do not necessarily apply to the teachers' specific teaching contexts (Erlam, 2008; Nassaji, 2012).

The discourse that appears in academic journals (referred to as "research-based discourse" by Ellis \& Shintani, 2014) may pose particular problems for those who are not members of the researcher community of practice. Stylistically, the conventions of academic writing favour prose that is concise, objective, and formal. In addition to following language and textual conventions, authors of research reports make assumptions about their readers' background knowledge in the discipline and familiarity with research design, techniques, statistics, etc. It comes as no surprise, then, that it has been found that teachers do not generally read research papers (e.g., Borg, 2010; Crookes \& Arakaki, 1999; Kennedy, 1997; Nassaji, 2012). The problem is not only that research reports are written in an inaccessible way. Kennedy (1997) points to other issues such as the lack of relevance of experimental studies preferred by educational researchers and the lack of authoritativeness that arises from trying to control for all external influences on learning.

The kind of teaching-related material that provides practical guidelines and that teachers do read is referred to as pedagogical discourse (Ellis \& Shintani, 2014). This is writing that is intended specifically for educators and takes a variety of forms such as teacher's guides, curriculum documents, websites, and newsletter articles. This kind of writing generally eschews heavy referencing to the literature and limits the amount of technical terminology. Important concepts are explained using practical examples and illustrations. Thus, it follows from the notion of distinct researchers' and teachers' worldviews that the sharing of insights from research needs to occur in pedagogical discourse venues. This, however, does not mean that teachers 
need to be aware of research and theory to be successful in their practice (Medgyes, 2017), but that such venues can help researchers show the value of their work.

In this study, teacher education textbooks were chosen in order to examine the transfer of research relating to the topic of corrective feedback. One of the main aims of teaching methods textbooks, as typically indicated in their preface/introduction, is to establish a foundation for novice language teachers to build their repertoire of teaching practices. Furthermore, we assume that such textbooks include advice that is up-to-date and evidencebased. To explore the validity of this assumption, we conducted a systematic analysis of the information provided about giving oral feedback in a collection of textbooks written for use in language teacher education courses focused on how to teach an L2. The following research questions were addressed:

1. To what extent is the topic of OCF treated in teaching methods textbooks?

2. To what extent is OCF research cited in the selected textbooks?

3. What are the major OCF-related topics addressed in the textbooks?

\section{Method}

\section{Textbook Selection}

The first step in this study was to identify teaching methods textbooks. Titles were identified through the university library catalogue, publishers' websites, and the recommended textbooks for teacher training courses such as CELTA and DELTA as well as for university courses for students preparing to be second language teachers (whether English or other target languages). Most importantly, the textbook needed to focus on pedagogical topics such as teaching language skills, lesson planning, and classroom management but not SLA research. Thus, for example, the popular How Languages are Learned by Lightbown and Spada (2013) was not selected given its focus on SLA research, indicated by the following extract from the book's introduction:

The goal of this book is to introduce teachers-both novice and experienced - to some of the language acquisition research that may help them not only to evaluate existing textbooks and materials but also to adapt them in ways that are more consistent with our understanding of how languages are learned. (p.1)

On the other hand, books such as Harmer's The Practice of English Language Teaching (2015) were selected due to their pedagogical orientation to issues related to L2 teaching in classroom. In order to focus on the textbooks 
published after the initial growth of OCF research, we used the year 2005 as our initial cut-off date of publication. However, many textbooks have multiple editions; for example, Harmer's books alone have been published for over 30 years (from 1983 to 2015). The multi-edition textbooks offered us the opportunity to examine trends over time; hence books with publication dates before the cut-off (ranging from 1979 to 2001) were included for a part of the analysis. As shown in Table 2, the final sample of 30 textbooks included four single-edition textbooks and seven textbook series, consisting of two to five editions. Of the 30 textbooks, two titles, The Cambridge Guide to Pedagogy and Practice in Second Language Teaching (Burns \& Richards, 2012) and Teaching English as a Second or Foreign Language (Celce-Murcia, 1979, 1991, 2001; CelceMurcia et al., 2014) are edited collections of chapters dealing with different pedagogical topics, written by different authors.

Table 2

The Selected Teaching Methods Textbooks

\begin{tabular}{|c|c|c|c|}
\hline Author/Editors & Year & Title & $\begin{array}{l}\text { \# of } \\
\text { Editions }\end{array}$ \\
\hline Brandl & 2008 & $\begin{array}{l}\text { Communicative Language Teaching in Action: } \\
\text { Putting Principles to Work }\end{array}$ & 1 \\
\hline Brown \& Lee ${ }^{a}$ & $\begin{array}{l}\text { 1994, 2001, } \\
2007,2015\end{array}$ & $\begin{array}{l}\text { Teaching by Principles: An Interactive } \\
\text { Approach to Language Pedagogy }\end{array}$ & 4 \\
\hline Burns \& Richards & 2012 & $\begin{array}{l}\text { The Cambridge Guide to Pedagogy and } \\
\text { Practice in Second Language Teaching }\end{array}$ & 1 \\
\hline $\begin{array}{l}\text { Celce-Murcia, } \\
\text { Brinton, \& Snow } \\
\text { b c }\end{array}$ & $\begin{array}{l}1979,1991 \\
2001,2014\end{array}$ & $\begin{array}{l}\text { Teaching English as a Second or Foreign } \\
\text { Language }\end{array}$ & 4 \\
\hline Edge \& Garton & 2009 & From Experience to Knowledge in ELT & 1 \\
\hline Harmer & $\begin{array}{l}1983,1991 \\
2001,2007 \\
2015\end{array}$ & The Practice of English Language Teaching & 5 \\
\hline Johnson & $\begin{array}{l}2001,2008, \\
2018\end{array}$ & $\begin{array}{l}\text { An Introduction to Foreign Language Learning } \\
\text { and Teaching }\end{array}$ & 3 \\
\hline $\begin{array}{l}\text { Li, Myles, \& } \\
\text { Robinson }\end{array}$ & 2012 & Teaching ESL in Canada & 1 \\
\hline Scrivener & $\begin{array}{l}1994,2005 \\
2011\end{array}$ & $\begin{array}{l}\text { Learning Teaching: The Essential Guide to } \\
\text { English Language Teaching }\end{array}$ & 3 \\
\hline
\end{tabular}


${ }^{a}$ All except for the last edition have Brown as the sole author.

${ }^{b}$ All except for the last edition have Celce-Murcia as the sole editor.

${ }^{c}$ The topic of feedback was addressed in chapters by Lazaraton, Bohlke, and Brinton.

\section{Procedure}

The selected textbooks were examined in terms of quantity of coverage and the content themes in the information about OCF. For the quantitative analysis, a protocol was developed to calculate the number of pages covering this topic (see Appendix A). The index of each book was visually scanned for OCF-related terms such as correction, feedback, error, fluency, accuracy, and mistake, and phrases including any of these words to locate the relevant pages. Coverage in this analysis was defined as three or more sentences dealing with $\mathrm{OCF}$ in instructed settings. Excluded from the analysis was any discussion of error correction in general, correction of written errors, correction in natural settings, correction during drills and controlled activities, correction in the context of teaching methods (e.g., Total Physical Response), and error analysis without reference to feedback; the focus of our analysis was on error correction, not the sources of errors, only during oral meaning-focused activities. Each page was divided into four quarters; the amount of text was quantified as being no coverage ( 0 ), one quarter of a page (0.25), two quarters $(0.50)$, three quarters (0.75), or one page. After adding up the number of relevant pages in each textbook, the total amount was divided by the number of pages in the book, excluding the table of contents, preface, reference list, index, appendix, glossary, end-of-book tasks, and any section without Arabic numerals. To check the reliability of the quantifying phase, a research assistant used the same protocol to calculate the amount of OCF coverage in eight textbooks randomly selected from the collection. The inter-rater reliability was 0.93 , which indicates a high level of agreement between the two raters.

To track changes in the amount of CF coverage from the first to the latest edition of a multi-edition textbook series (i.e., books with two or more series), percentage change was calculated by subtracting the amount of coverage in the first edition from that in the last edition divided by the former. This number expresses the change in amount of coverage in the latest edition as a percentage of the coverage in the first edition. A positive value suggests that there has been an increase in coverage while a negative value indicates a decrease (see Table 4 in the Results section for the percentage change values).

The next step involved in determining the extent to which CF research is reflected in the textbooks was to tally the number of sources cited when 
advice about OCF is given. Two types of sources were identified: (1) empirical articles that included quantitative and/or qualitative data analysis and (2) discussion articles that summarized and synthesized existing literature, explicated models and methods, or described practical issues arising in classrooms. Table 3 presents an example of the information about oral CF gleaned from Harmer (2015).

Table 3

Quantitative Information about Oral Corrective Feedback (OCF) in One Textbook

\begin{tabular}{l|l}
\hline Textbook & Harmer (2015) \\
\hline Page number & $157,158-161,287$ \\
\hline Total OCF pages & 1.25 \\
\hline Total book pages & 425 \\
\hline OCF pages/100 pages & 0.29 \\
\hline No. of empirical & 0 \\
\hline No. of discussion & 4 \\
\hline
\end{tabular}

To complement the quantitative analysis, the content in the textbooks dealing with OCF was analyzed using a two-tiered procedure consisting of topic and analytical coding (Richards, 2009). For this phase of the analysis, given that most OCF research has been published after 1997, only textbooks published after 2005 were selected. The information about oral CF that was identified in each textbook was first coded in terms of the topics covered. Topic was defined at two levels: the heading(s), if any, of the OCF sections and the ideas that were discussed in those sections. At the analytical stage, the OCF sections were examined in order to aggregate and label themes that repeated across at least five of the textbooks.

\section{Results}

Given the differing lengths of the textbooks, the amount of coverage per 100 pages (henceforth referred to as "coverage") was calculated to make the amounts comparable across the books. The coverage ranged from 0 to 2.36 pages $(M=0.83)$ across the 30 textbooks (see Appendix $B$ for all the coverage amounts). Burns and Richards (2012) has zero coverage of OCF while Brandl (2008) has the highest coverage $(M=2.36)$. Grouping the books into preand post-2005 texts, we found that those published before 2005 had a lower mean coverage (0.69) than those published afterwards (0.94); however, the difference was not statistically significant $(t(28)=-1.23, p=0.226)$. Harmer (2001) had the highest coverage $(M=1.55)$ among the pre-2005 textbooks, and Brandl (2008) had the highest coverage among those published after 2005. 


\section{Coverage across Editions}

The percentage change was calculated for the textbook series to find the amount of change in OCF coverage in the latest edition as a percentage of the coverage in the first edition (see Table 4). A negative value indicates a decrease while a positive value shows an increase.

Table 4

Percentage Change across Editions

\begin{tabular}{lllll}
\hline First Edition & Coverage & Latest Edition & Coverage & $\begin{array}{l}\text { Percentage } \\
\text { Change }\end{array}$ \\
\hline Brown (1994) & 1.02 & Brown \& Lee (2015) & 0.85 & $-17 \%$ \\
\hline Celce-Murcia (1979) & 0.48 & $\begin{array}{l}\text { Celce-Murcia et al. } \\
(2014)\end{array}$ & 0.69 & $44 \%$ \\
\hline Harmer (1983) & 0.21 & Harmer (2015) & 0.29 & $38 \%$ \\
\hline Johnson (2001) & 0 & Johnson (2018) & 1.42 & $142 \%$ \\
\hline Scrivener (1994) & 0.5 & Scrivener (2011) & 0.45 & $-10 \%$ \\
\hline $\begin{array}{l}\text { Shrum \& Glisan } \\
(1994)\end{array}$ & 0.54 & Shrum \& Glisan (2016) & 1.09 & $102 \%$ \\
\hline Ur (1996) & 0.97 & Ur (2012) & 0.69 & $-29 \%$ \\
\hline
\end{tabular}

Of the seven textbook series, four increased and three decreased in OCF coverage. The highest positive percentage change (142\%) was in Johnson (2018), which had no coverage of the topic in the first edition. The highest negative percentage change (-29\%) was in Ur (2012). The comparison of the mean coverage in the pre- and post-2005 editions of the textbook series showed an increase in the post-2005 editions of four books by Celce-Murcia, Harmer, Johnson, and Shrum and Glisan; a decrease was found in the post2005 editions in Brown, Scrivener, and Ur. The greatest increase (142\%) was observed in the series by Johnson $(2001,2008,2018)$ while the greatest decrease $(-29 \%)$ was found from the first to the second edition of Ur (1996, 2012).

\section{Citations of OCF Research}

The previous analysis reflects the extent to which the authors of the teaching methods textbooks have attached importance to the topic of OCF. The tally of citations of SLA literature reflects the representation of research in these textbooks. Among the textbooks that had at least 0.25 page of coverage, the number of unique OCF-focused citations (i.e., type) ranged from 0 to $18(M=$ 3.28). Eight textbooks, with OCF coverage ranging from 0.21 to 1.67 , did not have any relevant citations. For example, Edge and Garton (2009) with the third highest coverage (1.67) among all the textbooks did not have a single 
OCF-related citation. On the other hand, Brandl (2008), which had the highest coverage, included 18 relevant citations.

Among the textbooks that had at least one OCF-focused citation $(n=$ 20), 17 included only one to six relevant citations; Shrum and Glisan (2010), Shrum and Glisan (2016), and Brandl (2008) included 14, 12, and 18 unique citations, respectively. The number of unique empirical and discussion sources cited in these textbooks ranged from 0 to $16(M=2.03)$ and 0 to $4(M$ $=1.25$ ), respectively. Among the 20 textbooks that had at least one relevant citation, eight did not include any empirical sources, and two did not include any discussion articles.

The highest number of empirical sources (16 unique sources) is found in Brandl (2008), while the highest number of discussion articles (four unique sources) is cited in Harmer (2015) and Shrum and Glisan (2016). The most frequently cited empirical source is Lyster and Ranta (1997), which is cited 25 times in seven textbooks; of the 39 unique citations of the empirical sources, 31 were published after 1997 . The most frequently cited discussion article is Sheen and Ellis (2011), which is cited 10 times in three textbooks, followed by Vigil and Oller (1976) cited eight times in six textbooks.

Comparison of the number of relevant sources cited in the pre- and post2005 textbooks (Table 5) with at least one relevant citation revealed that the books published after 2005 included more relevant citations (tokens $=67$ ), ranging from 1 to 18 , than the pre-2005 texts (tokens $=25$ ) that ranged from 1 to 6. In terms of the OCF related citations, Celce-Murcia (2001) and Brandl (2008) included the highest number of relevant citations. The post-2005 textbooks included more tokens of empirical and discussion articles than the pre-2005 texts; there were 45 empirical and 22 discussion sources cited in the post-2005 books compared to the 12 empirical and 13 discussion articles cited in the pre-2005 textbooks.

Table 5

Number of Citations in Pre- and Post-2005

\begin{tabular}{llllll}
\hline Pre-2005 & Empirical & Discussion & Post-2005 & Empirical & Discussion \\
\hline Brown (1994) & 0 & 2 & Brandl (2008) & 16 & 2 \\
\hline Brown (2001) & 0 & 2 & Brown (2007) & 0 & 2 \\
\hline $\begin{array}{l}\text { Celce-Murcia } \\
(1979)\end{array}$ & 3 & 1 & Brown (2015) & 0 & 3 \\
\hline $\begin{array}{l}\text { Celce-Murcia } \\
(1991)\end{array}$ & 2 & 3 & $\begin{array}{l}\text { Celce-Murcia et al. } \\
(2014)\end{array}$ & 0 & 2 \\
\hline $\begin{array}{l}\text { Celce-Murcia } \\
(2001)\end{array}$ & 5 & 1 & Harmer (2007) & 1 & 2 \\
\hline $\begin{array}{l}\text { Harmer } \\
(2001)\end{array}$ & 0 & 2 & Harmer (2015) & 0 & 4 \\
\hline
\end{tabular}




\begin{tabular}{llllll}
\hline $\begin{array}{l}\text { Shrum \& } \\
\text { Glisan (1994) }\end{array}$ & 0 & 1 & Johnson (2008) & 1 & 1 \\
\hline $\begin{array}{l}\text { Shrum \& } \\
\text { Glisan (2000) }\end{array}$ & 2 & 1 & Johnson (2018) & 1 & 1 \\
\hline- & - & - & $\begin{array}{l}\text { Shrum \& Glisan } \\
(2005)\end{array}$ & 4 & 0 \\
\hline- & - & - & $\begin{array}{l}\text { Shrum \& Glisan } \\
(2010)\end{array}$ & 13 & 1 \\
\hline- & - & - & $\begin{array}{l}\text { Shrum \& Glisan } \\
(2016)\end{array}$ & 8 & 4 \\
\hline- & - & - & Ur (2012) & 1 & 0 \\
\hline Total & 12 & 13 & & 45 & 22 \\
\hline
\end{tabular}

\section{Thematic Content of Textbook Advice}

The qualitative content analysis focused on post-2005 textbooks that had at least a quarter of a page of OCF coverage. This yielded 16 textbooks under 10 different titles. Themes were labelled and grouped under categories based on the fundamental questions about error correction first posed by Hendrickson (1978): (1) When should errors be corrected? (2) Which errors should be corrected? (3) How should errors be corrected? (4) Who should correct errors? A fifth question was added: What are the affective consequences of error correction? Themes that were addressed in at least five textbooks are presented in Table 6 and discussed below.

Table 6

OCF-Related Themes Identified in the Textbooks

\begin{tabular}{|c|c|c|}
\hline Questions & $\begin{array}{l}\text { No. of different } \\
\text { titles (No. of all } \\
\text { the titles) }\end{array}$ & Textbooks addressing the themes \\
\hline $\begin{array}{l}\text { Whether and when should } \\
\text { errors be corrected? }\end{array}$ & $8(13)$ & $\begin{array}{l}\text { Celce-Murcia et al., 2014; Edge \& } \\
\text { Garton, 2009; Harmer, 2007; Harmer, } \\
\text { 2015; Johnson, 2008; Johnson, 2018; Li } \\
\text { et al., 2012; Scrivener, 2005; Scrivener, } \\
\text { 2011; Shrum \& Glisan, 2005; Shrum \& } \\
\text { Glisan, 2010; Shrum \& Glisan, 2016; } \\
\text { Ur, } 2012\end{array}$ \\
\hline $\begin{array}{l}\text { Which errors should be } \\
\text { corrected? }\end{array}$ & $6(9)$ & $\begin{array}{l}\text { Brown, 2007; Brown \& Lee, 2015; } \\
\text { Celce-Murcia et al., 2014; Edge \& } \\
\text { Garton, 2009; Harmer, 2007; Harmer, } \\
\text { 2015; Johnson, 2008; Johnson, 2018; } \\
\text { Shrum \& Glisan, 2016 }\end{array}$ \\
\hline
\end{tabular}




\begin{tabular}{|c|c|c|}
\hline $\begin{array}{l}\text { How should errors be } \\
\text { corrected? }\end{array}$ & $6(10)$ & $\begin{array}{l}\text { Brandl, 2008; Brown, 2007; Brown \& } \\
\text { Lee, 2015; Celce-Murcia et al., 2014; } \\
\text { Harmer, 2007; Harmer, 2015; Shrum \& } \\
\text { Glisan, 2005; Shrum \& Glisan, 2010; } \\
\text { Shrum \& Glisan, 2016; Ur, } 2012\end{array}$ \\
\hline Who should correct errors? & $5(8)$ & $\begin{array}{l}\text { Brown, 2007; Brown \& Lee, 2015; } \\
\text { Celce-Murcia et al., 2014; Edge \& } \\
\text { Garton, 2009; Harmer, 2007; Harmer, } \\
\text { 2015; Shrum \& Glisan, 2005; Shrum \& } \\
\text { Glisan, } 2010\end{array}$ \\
\hline $\begin{array}{l}\text { What are the affective } \\
\text { consequences of error } \\
\text { correction? }\end{array}$ & $5(7)$ & $\begin{array}{l}\text { Brandl, 2008; Brown, 2007; Brown \& } \\
\text { Lee, 2015; Harmer, 2007; Johnson, } \\
\text { 2008; Johnson, 2018; Shrum \& Glisan, } \\
2016\end{array}$ \\
\hline
\end{tabular}

\section{Whether and When Should Errors be Corrected?}

The most frequently addressed topic concerns whether and when teachers should correct errors during oral communicative activities. The authors discussing this issue generally advocate avoiding error correction during fluency activities and postponing it to the post-task phase. For example, in Lazaraton's chapter in Celce-Murcia et al. (2014), it is suggested that correction should be avoided during fluency activities because it disrupts the flow of communication. Similarly, Li et al. (2012) view teachers' corrections as interruptions, which they suggest may negatively affect language development. During fluency work, they recommend that teachers record (patterns of) errors and comment on them at the end of the fluency activity. More cautiously, Ur (2012) suggests that teachers "play it by ear" and use their intuition, previous experience, knowledge of their students, and other factors to decide whether they should or should not correct when students are engaged in communicative activities. Scrivener (2011) notes that if correction has to be provided during a communicative activity, it should be brief and unobtrusive. In Bohlke's chapter in Celce-Murcia et al. (2014), corrective strategies such as echoing and reformulation are suggested as ways of correcting during fluency activities.

\section{Which Errors Should be Corrected?}

Nine textbooks under six different titles discuss what errors teachers should correct. The issue is whether to correct every language problem or be more selective. There is a consensus among the textbook authors that overcorrection should be avoided. In Johnson's (2018) colourful metaphor, error correction is "a medicine where an overdose can kill" (p. 337). Thus, some authors argue that only certain language problems should be corrected. A distinction made by some is that between mistakes (or slips) in performance and errors that arise from lack of knowledge. According to Edge and Garton (2009), 
correction works for mistakes, but instruction is needed for errors. They further note that learners' developmental readiness should be considered when providing feedback, which should address problems that naturally occur in the course of interlanguage development. In direct contradiction of Edge and Garton, Brinton in her chapter in Celce-Murcia et al. (2014) considers feedback effective for errors but not for mistakes. More vaguely, Brown (2007) and Brown and Lee (2015) state that the decision to correct depends on the type and source of the error.

\section{How Should Errors be Corrected?}

Another common topic concerns how errors should be corrected. In Brown's (2007) view, teachers need to "develop the intuition, through experience and established theoretical foundations, for ascertaining which option or combination of options is appropriate at given moments" (p. 348). However, the other textbooks discussing this issue favour the feedback options that elicit the correct form from learners (i.e., output-prompting) over those that provide the correct form (i.e., input-providing). Giving learners the opportunity to self-correct makes students responsible for their own learning and gets them out of their traditional role as a learner to become a conversational participant (Shrum \& Glisan, 2010). Along similar lines, Ur (2012) remarks that feedback strategies that "get the student to rethink what he or she has said and produce the correct form, are significantly better" (pp. 95-96). In Shrum and Glisan (2005, 2010, 2016), it is argued that the most effective types of feedback are those that lead to the negotiation of form: elicitation, metalinguistic feedback, clarification request, and repetition. These strategies, they noted, lead to student-generated repair that can help learners revise their wrong hypotheses and restructure their interlanguage. However, Brandl (2008) cautions that some of these strategies, specifically elicitation and metalinguistic feedback, may disrupt focus on meaning and be time-consuming.

The benefits of using recasts, according to Brandl (2008), Shrum and Glisan (2016), and Ur (2012) is that they provide the correct form in an unobtrusive manner that allows teachers and students to stay focused on communication. That is why this type of feedback can be used during fluency activities, when a communication breakdown arises (Harmer, 2007, 2015). However, Brandl, Shrum and Glisan, and Ur also note that the corrective intention of recasts cannot be easily perceived, and they may be taken as an acknowledgement of what they said, rather than as correction. It is noted that various factors can affect the noticeability and effectiveness of recasts. Shrum and Glisan (2010), for example, suggest that recasts should be produced with rising intonation or facial expression so that learners will better notice them as correction. The authors also argue that recasts may be more noticeable to high-proficiency learners and those with greater metalinguistic knowledge. Furthermore, 
Brandl (2008) notes that recasts are more noticeable when they target one or a limited number of formal features. Brinton (2014) claims that recasts are more effective with linguistic problems that arise when students try to express something that they do not know how to say than when they cannot correct themselves on their own.

\section{Who Should Correct Errors?}

In eight textbooks under five unique titles, peer correction is recommended as the best pedagogical option. Edge and Garton (2009), for example, state that peer correction gets students engaged and fosters the idea that students can learn from each other. Shrum and Glisan $(2005,2010)$ recommend peer correction, especially for learners at advanced levels where they can take responsibility for their own learning. Also, some concerns about peer correction are addressed in the textbooks. For instance, Brown (2007) notes that peer correction in well-managed small groups can happen spontaneously and teachers shouldn't worry about the reinforcement of errors because "levels of accuracy maintained in unsupervised groups are as high as those in teacher-monitored whole-class work" (p. 228). Regarding the affective aspect of peer correction, Harmer (2007) cautions that some learners may not like being corrected by their peers, and so the teacher should mentally prepare students for cooperative work and peer correction.

\section{What Are the Affective Consequences of Error Correction?}

Several textbook authors express concern about the negative effects of error correction on learners' emotions. In general, the affective impacts are associated with too much correction. According to Shrum and Glisan (2016), "Excessive error correction ... has the potential to create anxiety, thwart motivation, and de-emphasize the focus on communication" (p. 267). Similarly, Brandl (2008) notes that CF may trigger anxiety and embarrassment for learners and this, in turn, may impact their learning experience. In Bohlke's chapter, it is argued that error correction can heighten learners' stress levels and disrupt their learning. But, according to Harmer (2015), there is a need to strike a balance as "too much correction may push our students back towards 'fear'. Too little may mean that we miss ideal opportunities for work on language" (p. 387). A balanced approach to error correction is recommended by several authors, but exactly what that means is likely to vary according to the learners' needs and the instructional environment(s) they are in.

\section{Discussion}

This study set out to investigate the extent to which the topic of error correction is covered and OCF scholarship is represented in 30 teaching methods textbooks. In terms of the coverage of OCF in the textbooks selected, 
we found considerable disparity. For example, OCF is not mentioned at all in Burns \& Richards (2012), 22 books (65\%) discuss OCF briefly, and 10 (29\%) treat feedback in some depth. With respect to change over time as evidenced by the comparison of different editions of the same textbook, we found that some of the authors increased their coverage of OCF whereas others decreased it. This variability was observed when we compared the first with the most recent edition and the pre-2005 with the post-2005 editions of the multi-edition textbooks.

Given the large body of research on OCF, the aim of research Question 2 was to measure the extent to which research findings were represented in the textbooks. The first set of analyses revealed that nine textbooks, some with over one page of coverage, did not include any relevant citations in support of the advice offered. The other textbooks had relatively few OCF relevant citations (from 1 to 6). It was also found that the authors of more recent textbooks (post-2005) tended to cite more empirical studies and provided more OCF relevant citations.

The final qualitative analysis involved examining the OCF-related topics discussed in the textbooks published after 2005. We classified five themes found in at least five different titles into categories based on the practical pedagogical questions posed by Hendrickson (1978). Here we consider the textbook authors' advice in relation to findings from SLA research as well as to the pedagogical recommendations put forth by Ellis (2009).

All the textbooks addressing the issue of when to respond to errors (Theme 1) recommend that when students are engaged in fluency activities, correction should be delayed and not supplied immediately after an error occurs. Delayed feedback, it is argued, avoids disrupting the flow of communication. The topic of the timing of feedback has only recently been addressed by SLA researchers (e.g., Arroyo \& Yilmaz, 2018; Li, 2020; Li et al., 2016; Quinn, 2014), and the results have been mixed. Li et al. (2016) found that an immediate-feedback group outperformed a delayed-feedback group on a delayed test of explicit knowledge of English passive voice but not on a test of implicit knowledge. Arroyo and Yilmaz (2018) found that immediate feedback was more effective than delayed feedback on an oral production test but not on a grammaticality judgment text. Quinn (2014) found no difference between the impact of immediate and delayed feedback. These results suggest that immediate feedback could be as effective as and, under certain conditions, more effective than delayed feedback. Consistent with the ambiguity of the evidence, Ellis (2009) recommends using immediate as well as delayed corrective strategies during oral work.

The issue of what errors should be corrected is another theme that emerged from the content analysis. Teachers are generally advised to avoid correcting all errors primarily because overcorrection may distract learners' attention from focusing on meaning and may cause anxiety. An important dimension to this issue comes from studies of learners' feedback preferences, 
which have revealed that some learners do want all their mistakes to be corrected. In a survey of 1328 ESL and 993 French-as-a-second-language (FSL) learners and their teachers in Quebec, Jean and Simard (2011) found that $54 \%$ of the ESL and $30 \%$ of the FSL students wanted their oral mistakes corrected "all the time." The teachers, however, primarily indicated that they were more willing to correct the mistakes that interfered with communication and those that pertained to the grammatical features that the students were expected to know. In a study that directly addressed the role of anxiety, Zhang and Rahimi (2014) found that a desire for frequent correction was reported by both low anxiety and high anxiety students in an EFL context. Yet, it is unclear whether the learners who report a desire to be corrected all of the time actually want every error addressed. Instead, they may simply want to receive more correction than they are currently exposed to in class. Further research may shed light on this topic. With respect to the divergent advice about whether teachers should correct mistakes and not errors or vice versa, $C F$ researchers cannot settle the matter since they focus on problems with specific language structures regardless of their source (Ellis, 2017).

The third theme concerns how errors are to be corrected. Most of the textbooks advise teachers to adopt corrective strategies that encourage selfcorrection (i.e., prompts) rather than provide the correct form, usually via recasts, for the learners. This is one facet of advice to teachers that can be easily linked to the research literature since the comparison of recasts and prompts is a high-profile research topic. Although several factors, such as instructional context and learners' proficiency, can affect the relative efficacy of recasts and prompts (Brown, 2016), two meta-analytic studies of CF (Li, 2010; Lyster \& Saito, 2010) found a larger effect size for prompts. Further, Lyster et al. (2013) in their state-of-the-art review article conclude that prompts are generally more effective than recasts.

The downgrading of recasts in some textbooks is illustrated by comparing the quoted material about recasts from the 1994 to 2016 editions of Shrum and Glisan's textbook, The Teacher's Handbook:

Another technique, particularly in beginning language instruction, is to acknowledge the student's response by rephrasing it in a correct manner. ... [this] type of error correction ... should be employed cautiously, in a very positive, helpful manner (1994, p. 168).

Recasts may have a place in the classroom but only if the teacher uses them in a salient manner and if learners are cognitively and linguistically to notice their corrective value (2010, p. 288).

Since recasts are often an implicit strategy, they may be less likely to promote learning than are explicit feedback strategies that make feedback clear and prompt learner output. (2016, p. 269). 
In the later editions, the OCF research literature and its implications for teaching are explicitly and extensively discussed in Shrum \& Glisan (2010, pp. 284-86; 2016, pp. 268-271) referring to the OCF typology from Lyster and Ranta (1997) and the concepts of uptake and repair. In this case, we can confidently conclude that research has indeed transferred to the pedagogical discourse. However, as indicated by the quantitative analyses, empirical research is visible in only a few of the 30 textbooks scrutinized in this study.

In addressing the issue of who should correct errors, many of the textbook authors emphasize the value of having peer correction. This has begun to be an active topic of research on two fronts, one focused on learners' preferences and the other on its effects on L2 development. Studies of learners' preferences have revealed that learners consider teacher feedback to be more effective, even when they are receptive to peer feedback, (e.g., Kaivanpanah et al., 2015; Zhang \& Rahimi, 2014; Zhu \& Wang, 2019). In Schulz (2001), for instance, only $15 \%$ of the Colombian and $13 \%$ of the U.S. language learners indicated that they would prefer peer over teacher correction. In Sato (2013), on the other hand, questionnaire and interview data revealed that EFL learners in Japan held a highly positive attitude towards peer correction and viewed it as conducive to L2 development. The acceptance and use of peer feedback as a resource for L2 learning can be promoted by training and awarenessraising activities (Fuji et al., 2016; Sato \& Ballinger, 2012; Sato \& Lyster, 2012). In Fuji et al. (2016), for instance, university-level learners of English provided more CF in learner-learner interactions following a session of metacognitive instruction on the benefits of negotiated interaction and feedback. Zhang and Rahimi (2014) found that EFL learners who had received an explanation about different aspects of error correction (e.g., timing of CF, significance of $\mathrm{CF}$, and choice of corrector) held a positive belief about CF, irrespective of how anxious they were about language learning. Peer feedback has also been shown to have a positive impact on L2 development. Sato and Lyster (2012) trained learners of English at a Japanese university to provide CF to their peers in response to errors arising during communicative activities. Results at the end of 10 hours of instruction and practice indicated improvement in learners' fluency and accuracy on posttests. Thus, peer correction research suggests that learners can benefit from it if they are aware of the value of L2 learning in a collaborative context free of stigmatizing pressure (Lyster et al., 2013). With respect to this topic, the textbook advice appears to converge with the research findings related to peer feedback. However, due to the recency of this research, the pedagogical advice the textbook authors have imparted is, presumably, based on "received wisdom" or their personal practical knowledge.

The last theme of the content analysis relates to the affective impact of error correction. Teachers are advised to consider the impact of error correction on their learners' emotional states. It is argued that some learners might view being corrected by teachers and peers as humiliating and/or stressful, 
which can affect their engagement in and experience of class activities. Along similar lines, Ellis (2009) warns of the negative affective consequences of too much feedback and recommends that teachers consider students' anxiety level when choosing to correct learners' errors. Unfortunately, there is little empirical data to confirm or contradict this advice. SLA researchers have primarily focused on the cognitive effects of error correction despite the fact that Vigil and Oller (1976) long ago argued that feedback always has both cognitive and affective consequences. Still, some signs of interest in the affective side of OCF are starting to appear. For example, Rassaei (2015) compared how learners, classified as low or high-anxiety (on a trait measure), responded to two different types of feedback; the low-anxiety group benefited more from metalinguistic feedback while the high-anxiety learners benefited more from recasts. While such findings are potentially useful for planning instruction, further research is needed to shed light on the microlevel effects of feedback on learners' emotions and ability to manage anxiety in light of being corrected.

In sum, there is some evidence of knowledge transfer between the textbooks' advice and research findings relating to recasts where research is cited and explained in terms of its pedagogical implications of particular studies. There is also some convergence of understanding stemming from different sources in the case of peer feedback. In other cases, the advice by textbook authors is not supported by empirical research.

Through this analysis, we have identified considerable differences in the way that the topic of oral corrective feedback is dealt with in the pedagogical discourse of teaching methods textbooks. All have the goal of establishing a foundation of pedagogical knowledge for the novice L2 teacher, yet they differ greatly in the degree to which they appear to value the scholarship of language teaching and learning as it relates to CF. Consider, for example, the following extracts from discussions of recasts in Harmer (2007) and Shrum and Glisan (2016):

Harmer (2007, p. 145): "Such reformulation is just a quick reminder of how the language should sound. It does not put the student under pressure, but clearly points the way to future correctness. Its chief attribute-in contrast to the other techniques mentioned above-is its unobtrusiveness."

Shrum and Glisan (2016, p. 269): "The primary advantage of recasts seems to be their potential to call learners' attention to form during communicative activities and interactions without interrupting communication and focus on meaning (Loewen \& Philip, 2006)."

Shrum and Glisan use the well-established label "recast" and cite a research article. The explanation for the advantage of recasts is given in terms of cognitive processes (attention to form). In contrast, Harmer calls this type of feedback "reformulation," which is potentially confusing because it is used 
differently by some researchers. Harmer does not refer to any sources for his ideas here and describes the function of this technique vaguely as "pointing the way to future correctness." Although Harmer may very well be a reader of the applied linguistics literature, he has not chosen to make the contributions from the researcher discourse visible to the student teacher.

\section{Conclusion}

The aim of this study was to look for evidence of knowledge transfer from researcher discourse to the pedagogical discourse of teacher education textbooks. We found that the classroom-relevant research on the topic of OCF is visible in some but not all of the methods textbooks surveyed. This is unfortunate since, as Ellis (2010) argues, teacher education is an ideal context for research to exert influence on teaching and the topic of corrective feedback is well suited for such an influence. Teacher educators are well situated to socialize future teachers to value the contribution of research. Yet, there is a danger that novice teachers may overgeneralize the pedagogical implications of research due to lack of training or experience in critically evaluating empirical studies. For example, a reader might conclude that recasts should be avoided since Lyster and Ranta (1997) found less evidence of learner uptake after recasts as compared to other types of OCF. To avoid drawing simplistic conclusions from research, students need to be given the opportunity to discuss the details of studies and to reflect deeply on the pedagogical implications in relation to their own beliefs and practices. Ideally, textbook authors and teacher educators would be staying abreast of what the classroom-based SLA researchers have discovered about OCF and other topics. However, the explosion of research in the field of language learning and teaching in general and on the topic of OCF in particular means that keeping up-to-date is not necessarily easy. SLA researchers doing practicerelevant research can play their part by communicating their findings and providing research syntheses in ways that are accessible to a wide audience, including teachers, not just the scholars in their own community of practice. This might be the most effective way to build a bridge between the separate worlds of the researcher and the practitioner.

Future studies could look at knowledge transfer on other well-researched topics, such as written corrective feedback or grammar instruction, in pedagogical discourse venues using the same or different methodology. One of the limitations of this study pertains to the method of identifying the OCFrelated texts within the books. Scanning the index of the textbooks rather than reading the books in their entirety may have led to some relevant sections being overlooked. Furthermore, the selection of the textbooks could have been done more systematically by, for example, surveying the instructors of teaching methods courses at universities and private institutions about the materials that they use in their classes. 


\section{Acknowledgement}

We would like to acknowledge Sarvenaz Hatami, Jacqueline Werstiuk, Shiran Wang who as graduate students contributed in different ways to the textbook analysis. We are also grateful for the constructive comments from the anonymous reviewers and the editors of TESL Canada Journal.

\section{The Authors}

Majid Nikouee is currently a PhD candidate in the TESL program in the Department of Educational Psychology at the University of Alberta. His research interests are centred around form-focused instruction, grammar teaching, and corrective feedback.

Leila Ranta is an associate professor in the TESL program in the Department of Educational Psychology at the University of Alberta. She has had a long-standing interest in the study of corrective feedback and the relationship between SLA research and language teaching.

\section{References}

Note. The symbol * indicates the textbooks that were surveyed for this study.

Ammar, A. (2008). Prompts and recasts: Differential effects on second language morphosyntax. Language Teaching Research, 12(2), 183-210.

Arroyo, D. C., \& Yilmaz Y. (2018). An open for replication study: The role of feedback timing in synchronous computer-mediated communication. Language Learning, 68(4), 1-31.

Bell, T. R. (2005). Behaviors and attitudes of effective foreign language teachers: Results of a questionnaire study. Foreign Language Annals, 38(2), 259-270.

Bohlke, D. (2014). Fluency-oriented second language teaching. In M. Celce-Murcia, D. M. Brinton, \& M. Ann Snow (Eds.), Teaching English as a second or foreign language (pp. 121-135). National Geographic Learning.

Borg, S. (2010). Language teacher research engagement. Language Teaching, 43(4), 391-429.

* Brandl, K. (2008). Communicative language teaching in action: Putting principles to work. Pearson Education.

Brinton, D. M. (2014). Tools and techniques of effective second/foreign language teaching. In M. Celce-Murcia, D. M. Brinton, \& M. A. Snow (Eds.), Teaching English as a second or foreign language (pp. 340-361). National Geographic Learning.

Brown, A. V. (2009). Students' and teachers' perceptions of effective foreign language teaching: A comparison of ideals. The Modern Language Journal, 93(1), 46-60.

Brown, D. (2016). The type and linguistic foci of oral corrective feedback in the L2 classroom: A meta-analysis. Language Teaching Research, 20(4), 436-458.

* Brown, H. D. (1994). Teaching by principles: An interactive approach to language pedagogy. Longman.

* Brown, H. D. (2001). Teaching by principles: An interactive approach to language pedagogy ( $2^{\text {nd }}$ ed.). Pearson Education.

* Brown, H. D. (2007). Teaching by principles: An interactive approach to language pedagogy ( $3^{\text {rd }}$ ed.). Pearson Education.

* Brown, H. D., \& Lee, H. (2015). Teaching by principles: An interactive approach to language pedagogy ( $4^{\text {th }}$ ed.). Pearson Education.

* Burns, A, \& Richards, J. (Eds.). (2012). The Cambridge guide to pedagogy and practice in second language teaching. Cambridge University Press.

* Celce-Murcia, M. (1979). Teaching English as a second or foreign language. Newbury House Publishers.

* Celce-Murcia, M. (1991). Teaching English as a second or foreign language ( $2^{\text {nd }}$ ed.). Heinle \& Heinle Publishers.

* Celce-Murcia, M. (2001). Teaching English as a second or foreign language ( $3^{\text {rd }}$ ed.). Heinle \& Heinle Publishers. 
* Celce-Murcia, M., Brinton, D. M., \& Snow, M. A. (2014). Teaching English as a second or foreign language ( $4^{\text {th }}$ ed.). National Geographic Learning.

Chaudron, C. (1977). A descriptive model of discourse in the corrective treatment of learners' errors. Language Learning, 27(1), 29-46.

Crookes, G., \& Arakaki, L. (1999). Teaching idea sources and work conditions in an ESL program. TESOL Journal, 8, 15-19.

* Edge, J., \& Garton, S. (2009). From experience to knowledge in ELT. Oxford University Press.

Ellis, R. (2009). Corrective feedback and teacher development. L2 Journal, 1(1), 3-18.

Ellis, R. (2010). Second language acquisition, teacher education and language pedagogy. Language Teaching, 43(2), 182-201.

Ellis, R. (2017). Oral corrective feedback in L2 classrooms: What we know so far. In H. Nassaji, \& E. Kartchava (Eds.), Corrective feedback in second language teaching and learning (pp. 3-18). Routledge.

Ellis, R., Basturkmen, H., \& Loewen, S. (2001). Learner uptake in communicative ESL lessons. Language Learning, 51(2), 281-318.

Ellis, R., Loewen, S., \& Erlam, R. (2006). Implicit and explicit corrective feedback and the acquisition of L2 grammar. Studies in Second Language Acquisition, 28(2), 339-368.

Ellis, R., \& Shintani, N. (2014). Exploring language pedagogy through second language acquisition research. Routledge.

Erlam, R. (2008). What do you researchers know about language teaching? Bridging the gap between SLA research and language pedagogy. Innovation in Language Learning and Teaching, 2(3), 253-267.

Fanselow, J. (1977). Beyond RASHOMON-Conceptualizing and describing the teaching act. TESOL Quarterly, 11(1), 17-39.

Fuji, A., Ziegler, N., \& Mackey, A. (2016). In M. Sato \& Ballinger, S. (Eds.), Peer interaction and metacognitive instruction in the EFL classroom: Pedagogical potential and research agenda (pp. 63-89). John Benjamins.

* Harmer, J. (1983). The practice of English language teaching. Longman.

* Harmer, J. (1991). The practice of English language teaching (2 ${ }^{\text {nd }}$ ed.). Longman.

${ }^{*}$ Harmer, J. (2001). The practice of English language teaching ( $3^{\text {rd }}$ ed.). Longman.

* Harmer, J. (2007). The practice of English language teaching ( $\left.{ }^{\text {th }} \mathrm{ed}.\right)$. Longman.

* Harmer, J. (2015). The practice of English language teaching ( $5^{\text {th }}$ ed.). Pearson Education Limited.

Hendrickson, J. M. (1978). Error correction in foreign language teaching: Recent theory, research, and practice. The Modern Language Journal, 62(8), 387-398.

Jean, G., \& Simard, D. (2011). Grammar learning in English and French L2: Students' and teachers' beliefs and perceptions. Foreign Language Annals, 44(4), 465-492.

Jensen, M. T. (2001). Corrective feedback to spoken errors in adult ESL classrooms [Unpublished doctoral dissertation]. Monash University, Australia.

* Johnson, K. (2001). An introduction to foreign language learning and teaching. Pearson Education.

* Johnson, K. (2008). An introduction to foreign language learning and teaching ( $2^{\text {nd }} \mathrm{ed}$.). Routledge.

* Johnson, K. (2018). An introduction to foreign language learning and teaching ( ${ }^{\text {rd }}$ ed.). Routledge.

Kaivanpanah, S., Alavi, S. M., \& Sepehrinia, S. (2015). Preferences for interactional feedback: Differences between learners and teachers. The Language Learning Journal, 43(1), 74-93. https://doi.org/10.1080/09571736.2012.705571

Kartchava, E., \& Ammar, A. (2014). The noticeability and effectiveness of corrective feedback in relation to target type. Language Teaching Research, 18(4), 428-452.

Kennedy, M. (1997). The connection between research and practice. Educational Researcher, 26(7), $4-12$.

Labaree, D. F. (2003). The peculiar problems of preparing educational researchers. Educational Researcher, 32(4), 13-22.

Lee, E. (2013). Corrective feedback preferences and learner repair among advanced ESL students. System, 41(2), 217-230. 
Li, S. (2010). The effectiveness of corrective feedback in SLA: A meta-analysis. Language Learning, $60(2), 309-365$.

$\mathrm{Li}, \mathrm{S}$. (2020). What is the ideal time to provide corrective feedback? Replication of Li, Zhu \& Ellis (2016) and Arroyo \& Yilmaz (2018). Language Teaching, 53(1), 96-108.

Li, S., Zhu, Y., \& Ellis, R. (2016). The effects of the timing of corrective feedback on the acquisition of a new linguistic structure. Modern Language Journal, 100 (1), 276-295.

* Li, X., Myles, J., \& Robinson, P. (2012). Teaching ESL in Canada. Oxford University Press.

Lightbown, P. M., \& Spada, N. (2013). How languages are learned (4 $4^{\text {th }}$ ed.). Oxford University Press.

Loewen, S. (2012). The role of feedback. In S. M. Gass \& A. Mackey (Eds.), The Routledge handbook of second language acquisition (pp. 24-40). Routledge.

Long, M., \& Robinson, P. (1998). Focus on form: Theory, research, and practice. In C. Doughty \& J. Williams (Eds.), Focus on form in classroom language acquisition. Cambridge University Press.

Lyster, R. (2004). Differential effects of prompts and recasts in form-focused instruction. Studies in Second Language Acquisition, 26(3), 399-432.

Lyster, R., \& Ranta, L. (1997). Corrective feedback and learner uptake: Negotiation of form in communicative classrooms. Studies in Second Language Acquisition 19(1), 37-66.

Lyster, R., \& Saito, K. (2010). Oral feedback in classroom SLA: A meta-analysis. Studies in Second Language Acquisition, 32(2), 265-302.

Lyster, R., Saito, K., \& Sato, M. (2013). Oral corrective feedback in second language classrooms. Language Teaching, 46(1), 1-40.

Mackey, A., \& Goo, J. (2007). Interaction research in SLA: A meta-analysis and research synthesis. In A. Mackey (Ed.), Conversational interaction and second language acquisition. A series of empirical studies (pp. 377-419). Oxford University Press.

Medgyes, P. (2017). The (ir)relevance of academic research for the language teacher. ELT Journal, 71(4), 491-498.

Nassaji, H. (2012). The relationship between SLA research and language pedagogy: Teachers' perspectives. Language Teaching Research, 16(3), 337-365.

Nassaji, H., \& Kartchava, E. (Eds.). (2017). Corrective feedback in second language teaching and learning: Research, theory, applications, implications. Routledge.

Quinn, P. (2014). Delayed versus immediate corrective feedback on orally produced passive errors in English [Unpublished doctoral dissertation]. University of Toronto, Toronto.

Rassaei, E. (2015). Oral corrective feedback, foreign language anxiety and L2 development. System, 49, 98-109.

Richards, L. (2009). Handling qualitative data: A practical guide. Sage.

Russell, J., \& Spada, N. (2006). The effectiveness of corrective feedback for second language acquisition: A meta-analysis of the research. In J. Norris \& L. Ortega (Eds.), Synthesizing research on language learning and teaching (pp. 133-164). John Benjamins.

Sato, M. (2013). Beliefs about peer interaction and peer corrective feedback: Efficacy of classroom intervention. The Modern Language Journal. 97(3), 611-633.

Sato, M., \& Ballinger, S. (2012). Raising language awareness in peer interaction: A cross-context, cross-method examination. Language Awareness, 21(1-2), 157-179.

Sato, M., \& Lyster, R. (2012). Peer interaction and corrective feedback for accuracy and fluency development: Monitoring, practice, and proceduralization. Studies in Second Language Acquisition, 34(4), 591-626.

Schulz, R. A. (2001). Cultural differences in student and teacher perceptions concerning the role of grammar instruction and corrective feedback: USA-Colombia. Modern Language Journal, 85(2), 244-258.

* Scrivener, J. (1994). Learning teaching: A guidebook for English language teachers. Heinemann.

* Scrivener, J. (2005). Learning teaching: A guidebook for English language teachers ( $2^{\text {nd }}$ ed.). Macmillan.

* Scrivener, J. (2011). Learning teaching: The essential guide to English language teaching ( ${ }^{\text {rd }}$ ed.). Macmillan.

Sheen, Y. (2004). Corrective feedback and learner uptake in communicative classrooms across instructional settings. Language Teaching Research, 8(3), 263-300. 
Sheen, Y., \& Ellis, R. (2011). Corrective feedback in language teaching. In E. Hinkel (Ed.), Handbook of research in second language teaching and learning (Vol. 2, pp. 593-610). Routledge.

* Shrum, J. L., \& Glisan, E. W. (1994). Teacher's handbook: Contextualized language instruction. Heinle \& Heinle Publishers.

* Shrum, J. L., \& Glisan, E. W. (2000). Teacher's handbook: Contextualized language instruction (2 ${ }^{\text {nd }}$ ed.). Heinle \& Heinle Publishers.

* Shrum, J. L., \& Glisan, E. W. (2005). Teacher's handbook: Contextualized language instruction ( $3^{\text {rd }}$ ed.). Heinle \& Heinle Publishers.

* Shrum, J. L., \& Glisan, E. W. (2010). Teacher's handbook: Contextualized language instruction ( $^{\text {th }}$ ed.). Heinle Cengage Learning.

* Shrum, J. L., \& Glisan, E. W. (2016). Teacher's handbook: Contextualized language instruction (5 ${ }^{\text {th }}$ ed.). Cengage Learning.

Takahashi, N. (2014). Stressed intonation on recasts: Differential effects in comparison with prompts. The Journal of Language Learning and Teaching, 4(2), 15-28.

* Ur, P. (1996). A course in language teaching: Practice and theory. Cambridge University Press.

* Ur, P. (2012). A course in English language teaching (2 ${ }^{\text {nd }}$ ed.). Cambridge: Cambridge University Press.

Van de Guchte, M., Braaksma, M., Rijlaarsdam, G., \& Bimmel, P. (2015). Learning new grammatical structures in task-based language learning: The effects of recasts and prompts. The Modern Language Journal, 99(2), 246-262.

Vigil, N. A., \& Oller, J. W. (1976). Rule fossilization: A tentative model. Language Learning, 26(2), 281-295.

Yoshida, R. (2008). Learners' perception of corrective feedback in pair work. Foreign Language Annals, 41(3), 525-541.

Zhang, L. J., \& Rahimi, M. (2014). EFL learners' anxiety level and their beliefs about corrective feedback in oral communication classes. System, 42, 429-439.

Zhu, Y., \& Wang, B. (2019). Investigating English language learners' beliefs about oral corrective feedback at Chinese universities: A large-scale survey. Language Awareness, 28(2), 139-161. https://doi.org/10.1080/09658416.2019.1620755 


\section{Appendix A}

\section{Protocol for Identifying and Computing Coverage}

\section{Step 1}

Find the pages that cover OCF by scanning the index for the following words and any phrases containing these words:

"accuracy", "fluency", "focus on form", "recast", "elicitation", "feedback", "form-focused instruction", "error", "mistake", "correction", "error correction", "corrective feedback", "oral feedback", "oral error correction", "peer correction", "peer feedback"

\section{Step 2}

Specify the pages that cover OCF in a communicative context. Exclude the following: (1) $\mathrm{CF}$ in general (2) CF in natural settings (e.g., provided by parents or native speakers) (3) CF discussed in the context of specific teaching methods (e.g., Silent Way, Total Physical Response) (4) Sources and types of errors discussed in isolation and not in the context of oral error correction (5) Feedback on content (6) CF provided during drills/controlled practice activities.

\section{Step 3}

Divide each page into 4 quarters to determine the amount of coverage (three or more sentences count as coverage). Add up the number of pages covering OCF, divide the sum by the total number of pages in the book, and multiply it by 100 to get the amount of coverage per 100 pages.

NB: The total number of pages in a textbook excludes the table of contents, introduction, reference list, indexes, end-of-book activities/tasks/answers, glossaries, and any other section either at the beginning or end that does not have Arabic numerals. 


\section{Appendix B}

Coverage Amount in the Textbooks

\begin{tabular}{|c|c|c|c|}
\hline Textbook Title & $\begin{array}{l}\text { Total No. of } \\
\text { Pages }\end{array}$ & $\begin{array}{l}\text { Total } \\
\text { Coverage }\end{array}$ & $\begin{array}{l}\text { Coverage/100 } \\
\text { Pages }\end{array}$ \\
\hline Brandl (2008) & 10 & 422 & 2.36 \\
\hline Brown (1993) & 4.5 & 441 & 1.02 \\
\hline Brown $(2001,2$ nd ed.) & 6 & 446 & 1.34 \\
\hline Brown $(2007,3 r d$ ed.) & 6.25 & 522 & 1.19 \\
\hline Brown \& Lee $(2015,4$ th ed.) & 5 & 587 & 0.85 \\
\hline Burns \& Richards (2012) & 0 & 293 & 0 \\
\hline Celce-Murcia (1979) & 1.75 & 364 & 0.48 \\
\hline Celce-Murcia (1991, 2nd ed.) & 3 & 516 & 0.58 \\
\hline Celce-Murcia (2001, 3rd ed.) & 3 & 550 & 0.54 \\
\hline Celce-Murcia et al. (2014, 4 th ed.) & 4.5 & 645 & 0.69 \\
\hline Edge \& Garton (2009) & 3 & 179 & 1.67 \\
\hline Harmer (1983) & 0.5 & 236 & 0.21 \\
\hline Harmer (1991, 2nd ed.) & 1.25 & 275 & 0.45 \\
\hline Harmer (2001, 3rd ed.) & 5.5 & 353 & 1.55 \\
\hline Harmer $(2007,4$ th ed.) & 5.25 & 416 & 1.26 \\
\hline Harmer $(2015,5$ th ed.) & 1.25 & 425 & 0.29 \\
\hline Johnson (2001) & 0 & 336 & 0 \\
\hline Johnson (2008, 2nd ed.) & 5.5 & 346 & 1.58 \\
\hline Johnson (2018, 3rd ed.) & 4.25 & 299 & 1.42 \\
\hline Li et al. (2012) & 0.75 & 269 & 0.27 \\
\hline Scrivener (1994) & 1 & 200 & 0.5 \\
\hline Scrivener (2005, 2nd ed.) & 1.25 & 370 & 0.33 \\
\hline Scrivener (2011, 3rd ed.) & 1.75 & 385 & 0.45 \\
\hline Shrum \& Glisan (1994) & 1.5 & 275 & 0.54 \\
\hline Shrum \& Glisan (2000, 2nd ed.) & 3.25 & 360 & 0.90 \\
\hline Shrum \& Glisan (2005, 3rd ed.) & 4 & 442 & 0.90 \\
\hline Shrum \& Glisan (2010, 4th ed.) & 5.25 & 510 & 1.02 \\
\hline Shrum \& Glisan (2016, 5th ed.) & 4.75 & 434 & 1.09 \\
\hline Ur (1996) & 3.5 & 359 & 0.97 \\
\hline Ur (2012, 2nd ed.) & 2.5 & 325 & 0.69 \\
\hline
\end{tabular}

